\title{
Senecio pseudoarnica Less. (Asteraceae) - a new non-native species invading coastal areas in arctic and subarctic Europe
}

Pawel Wasowicz ( $\square$ pawasowicz@gmail.com )

Icelandic Institute of Natural History https://orcid.org/0000-0002-6864-6786

Torbjørn Alm

UiT Arctic University of Norway: UiT Norges arktiske universitet

\section{Research Article}

Keywords: Iceland, Norway, Senecio pseudoarnica, invasive species, Arctic, Subarctic

Posted Date: February 15th, 2021

DOl: https://doi.org/10.21203/rs.3.rs-221810/v1

License: (c) (i) This work is licensed under a Creative Commons Attribution 4.0 International License.

Read Full License

Version of Record: A version of this preprint was published at Biological Invasions on March 11th, 2022. See the published version at https://doi.org/10.1007/s10530-022-02759-w. 


\section{Abstract}

We report the human-assisted spread of Senecio pseudoarnica, native to the northern coasts of North America and the Far East, to arctic and subarctic regions of Europe. Our findings indicate that the species, imported as a decorative plant, is currently rapidly spreading along coastal areas of Iceland and Norway. An exponential model comprehensively explained the increase in the number of known localities. Close climate matching between the native and non-native ranges (shown by our preliminary analyses), as well as practically exact environmental matching, are the main factors that facilitate the process of naturalisation and invasion. S. pesudoarnica is one of the very few species invading these arctic and subarctic regions.

\section{Introduction}

The Arctic and Subarctic are among the few areas in the world where ecosystems remain only minimally affected by non-native plant species, and where only a small number of non-native plants are considered to be invasive (Wasowicz et al. 2020). This is mainly because these regions are inhabited by small human populations, which generates limited large-scale human disturbance, modest traffic volumes and low propagule pressure (Lassuy and Lewis 2013). Harsh climatic conditions and a short growing season are the main constraints that limit the invasion of more southern species (Alsos et al. 2015). However, with warming climates and growing human populations, these constraints are now weaker, indicating that, in the future, the Arctic and Subarctic may become an arena for plant invasions on an unprecedented scale, as no biosecurity measures are currently in place to protect these fragile ecosystems (Wasowicz et al. 2020).

Here, we report on the spread of Senecio pseudoarnica to the arctic and subarctic regions of northern Europe. To date, this species is known only from its native range covering the North Atlantic coasts of North America (from Nova Scotia, Gulf of St. Lawrence and Newfoundland to Labrador Peninsula) as well as the Northern Pacific coast (from Japan and British Columbia to the Bering Strait) (Fig 1.) In the present paper we document the species' present non-native range, time of residence and pathway of its introduction to Europe, describe basic ecological data and estimate the dynamics of its expansion.

\section{Materials And Methods}

\section{Data acquisition in the native and introduced distribution areas}

We searched all available data sources, including gardening books and catalogues, data from botanical gardens and other relevant sources, for information on the time that $S$. pseudoarnica was first imported to Iceland and Norway. Data on the species distribution in Iceland and Norway were collected during field excursions carried out by the authors, by searching local databases (from both countries), as well as by directly contacting individuals who had sightings of the species. Each occurrence point was confirmed either via collections stored in the AMNH and TROM herbaria or, at a minimum, by a high-quality 
photograph. All occurrence points were georeferenced either directly (using a GPS unit) or indirectly. Fully georeferenced point distribution data from the native distribution range were downloaded from GBIF (2021).

Climatic data and inference on environmental conditions in the native and introduced distribution areas

Climatic data representative for 1970-2000 were downloaded as bioclimatic variables from WorldClim version 2.1 (Fick and Hijmans 2017). These variables, derived from monthly temperature and rainfall values, are more biologically relevant and are often used in species distribution modelling and other ecological modelling techniques. We used all 19 variables representing annual trends, as well as extreme or limiting environmental factors. WorldClim data were sampled from bioclimatic variables using point distribution data from the native and introduced distributions. GIS layers were sampled using sample raster values integrated into QGIS (QGIS Development Team 2021). The resulting database containing 19 values for each site (point) of natural and introduced distribution (301 in total: 258 from natural distribution range, 31 from Iceland and 12 from Norway) was further analysed using principal component analysis (PCA) with the prcomp) function of the factoextra package in R (Kassanbra 2020). Results of PCA were visualised as a 3D scatter plot using the plot3D package (Soetaert 2013).

\section{Linear and non-linear model fitting}

The relationship between the number of localities and time was assessed by fitting a linear and nonlinear model to our observation. Regression models were fitted using the $\operatorname{Im}()$ function in R (R Core Team 2013). Predictions and $95 \%$ prediction intervals were calculated using the predict() function in R. All $p$ values are two-tailed.

\section{Results}

\section{Distribution and ecology}

Iceland

In Iceland, the presence of $S$. pseudoarnica was confirmed in more than 30 sites along the whole coastline (Fig. 2), and several localities were also discovered inland. The species is typically present on beaches above or on the drift line, as well as on backshore berms formed from organic matter deposited by the ocean. It grows in plant communities dominated by Leymus arenarius and Mertensia maritima often classified as Icelandic sand beach perennial communities. S. pseudoarnica can also thrive and reproduce on upper shingle beaches with open vegetation, between pebbles and cobbles, with limited sources of organic matter. Inland sites in Iceland include mostly man-made habitats such as bar ditches, roadsides, or garden waste disposal sites. S. pseudoarnica was also identified from a streamside. Regardless of location, this species usually forms dense monotypic stands. The spread of numerous single plants over wide areas suggests that reproduction by seeds occurs, at a minimum, in a few locations in southern Iceland. 
So far, approximately 50 stands of $S$. pseudoarnica have been recorded in northern Norway (Fig. 2). Most (except four) of these are in seashore habitats, and only one is a little more than $100 \mathrm{~m}$ away from the shoreline. Based on extant records, sandy shores are their preferred habitat, with these stands being by far the largest found in habitats otherwise dominated by Leymus arenarius (and, in a single site, Alopecurus arundinaceus). S. pseudoarnica can potentially also grow on gravelly shores, but seemingly not in areas dominated by silt or clay. Smaller stands exist on driftwalls of kelp, associated with annual or perennial herbs, e.g. Atriplex prostrata and Honckenya peploides. Outside of near-shore areas, $S$. pseudoarnica has, to date, only been recorded in compost heaps associated with gardens, and on the meadow slopes of downside gardens. It thrives on fertile soils forming dense stands.

\section{Time of residence and pathway of introduction}

Iceland

The first account of the presence of S. pseudoarnica in Iceland dates back to 1968, from the registers of the Botanical Garden in Reykjvík. An index card containing information on the species mentions that the plant material was transferred to Reykjavík from Skrúður, the oldest botanical garden in Iceland, located in the Western Fjords. The species was subsequently removed from the Botanical Garden in Reykjavík owing to its markedly expansive properties, which created diffıculties for the staff (Hjörtur Porbjörnsson pers. comm.). The presence of S. pseudoarnica was also confirmed from the Botanical Garden in Akureyri, based on Index Seminum from the 1970s; however, the origin of plant material and time of its arrival is unknown. An expedition organised by the Icelandic Forest Service to the Russian Far East collected and, subsequently, imported seeds of the species from Talan island in Magadan Oblast in 1989 (Tómasson 1992). Today, S. pseudoarnica is grown in private gardens.

\section{Norway}

The species was imported from Alaska by a well-known horticulturist in Nordkjosbotn (Balsfjord, Troms $\varnothing$ ), circa 1990. From his garden, it could be tracked to several other gardens in Lenvik and Troms $\varnothing$ municipalities as an ornamental plant. Because its growth was difficult to control, the species was often removed from gardens to compost heaps.

\section{Climate matching}

We performed PCA on the data matrix containing the climatic characteristics of locations with a confirmed presence of the species in both the native and non-native ranges. The first three principal components explained over $80 \%$ of the total variance. Our analyses (Fig. 3) showed the Norwegian populations (yellow points) that are located within the cloud of points from the native range (green points) (Fig. 3). Conversely, Icelandic populations (blue points; Fig. 3) appear to cluster together on the margin of the cloud of points from the native range. 
Icelandic data were fitted with a linear and exponential model. The results revealed that the linear model (Fig. 4A) explained approximately $71 \%$ of the total variance (adjusted $R^{2}=0.713, p=2.425 \times 10^{-12}$ ), whereas the exponential model (Fig. 4B) explained more than $90 \%$ of the variance (adjusted $R^{2}=0.9077$, $\left.\mathrm{p}=2.2 \times 10^{-16}\right)$.

Similarly, Norwegian data were fitted with linear and exponential models. The results showed that the linear model explained approximately 76\% (Fig. 4E) (adjusted $R^{2}=0.7601, p=2.959 \times 10^{-5}$ ) of the total variance, whereas the exponential model explained approximately $43 \%$ (Fig. 4F) (adjusted $R^{2}=0.4345, p$ $=0.006166)$.

\section{Discussion}

Our data clearly show that $S$. pseudoarnica is a new non-native species naturalised in at least two regions of northern Europe (Iceland and Northern Norway). This data also evidently indicate that the species meets all the criteria to be classified as invasive (Richardson et al. 2000). S. pseudoarnica is currently invading natural coastal habitats in both regions. The first isolated population found in Sandøya (N Norway) in 2007 (Sortland et al. 2007) and hypothesised to be a product of trans-Atlantic natural dispersal was undoubtedly already the product of an ongoing invasion process (Alm and Often 2008). We acknowledge that our data is most probably incomplete and that more populations are present in both countries. Unfortunately, both Iceland and Norway are characterised by extremely long and diverse coastlines that are generally difficult to access.

\section{Residence time}

It is evident that S. pseudoarnica arrived in Iceland before 1960; however, owing to the lack of more detailed sources, we were unable to provide a more accurate arrival date. The first observations of wild populations on the seashore dates back to 1980, which suggests that approximately two decades had passed from the species' introduction to the first sightings. In Norway, the time between the importation of the species and discovery of the first wild populations is approximately 16 years.

\section{Pathway of introduction}

S. pseudoarnica was introduced to both countries as an ornamental plant. There is little doubt that rhizomes were removed from gardens and disposed of into the ocean (or close to the ocean shore) together with other gardening waste (a practice popular in Iceland), producing the first Icelandic populations of the species. In Norway, compost heaps served as an intermediate habitat, before the species reached natural coastal habitats. 
Field observations from both countries suggest that $S$. pseudoarnica is colonising habitats that are almost the same as within the native range (Talbot and Talbot 1984), e.g. beach meadows, located on young dunes that are influenced by salt spray on lower foredunes. It seems, therefore, that in both regions within its non-native range, the species is invading natural habitats, taking advantage of perfect environmental matching. In addition, we found that man-made habitats (e.g. roadsides and ditches) are also readily colonised by this species and are likely to act as corridors for further inland spread. A high degree of climatic matching was evidenced by our analyses, where Norwegian populations were placed within the cloud of points formed by localities from the native range of the species. Conversely, points representing Icelandic range were located on the margin of the cloud of points formed by localities from the native range, suggesting some degree of differentiation. This high degree of matching is certainly a factor that will increase the reproductive success of $S$. pseudoarnica in its non-native range.

\section{Expansion dynamics}

Estimates of the spreading dynamics were based on the number of known localities of the species. These calculations suggested that, in Iceland, the species have reached the expansion phase, characterised by an exponential growth in abundance (Arim et al. 2006). In Norway, S. pseudoarnica appears to still be in the initial establishment phase, characterised by a slow spread (Arim et al. 2006). However, recent field observations in northern Norway that documented thousands of flowering stems spread across approximately $2 \mathrm{~km}$ of shoreline along the seashore at the Slettmo area in Balsfjord, and a single outlier 7 $\mathrm{km}$ further north (Alm 2020), suggest that the expansion phase may already be underway.

\section{Declarations}

\section{Funding}

No funding was received for this work.

\section{Conflicts of interest}

The authors declare no conflict of interest.

\section{Availability of data and material}

New distribution data collected during this study is made available through GBIF doi: (here the doi of the GBIF dataset will be inserted)

\section{Authors' contributions}

PW conceived and designed the study. PW analysed the data. PW and TA contributed data. PW and TA wrote the paper.

\section{Acknowledgements}


The authors wish to thank Hjörtur Porbjörnsson and Hafsteinn Hafliðason for their assistance in locating sources on the first importation of the species to Iceland.

\section{References}

Alm T (2020) Strandsvineblom Senecio pseudoarnica er etablert art i Troms - og en pestplante. Blyttia 78: $265-271$.

Alm T, Often A (2008) Fire nye funn av strandsvineblom Senecio pseudoarnica i Troms $\varnothing$ - og en revurdering av opphavet. Blyttia 66: 244-251.

Alsos IG, Ware C, Elven R (2015) Past Arctic aliens have passed away, current ones may stay. Biol. Invasions 17: 3113-3123. https://doi.org/10.1007/s10530-015-0937-9.

Arim M, Abades SR, Neill PE, Lima M, Marquet PA (2006) Spread dynamics of invasive species. Proc. Natl. Acad. Sci. U.S.A. 103(2): 374-378.

Fick SE, Hijmans RJ (2017) WorldClim 2: new 1-km spatial resolution climate surfaces for global land areas. Int. J. Climatol. 37(12): 4302-4315.

GBIF.org (2021) GBIF Occurrence Download https://doi.org/10.15468/dl.zhre3x

Kassanbra A (2020). factoextra: Extract and Visualize the Results of Multivariate Data Analyses, R package version 1.0.7. https://www.rdocumentation.org/packages/factoextra Accessed 29 January 2021

Lassuy DR, Lewis PN (2013) Invasive species: Human-induced. In: Meltofte H, Josefson AB, Payer D (eds) Arctic biodiversity assessment. Status and trends in Arctic biodiversity, Conservation of Arctic Flora and Fauna, Akureyri pp. 450-458 http://arcticlcc.org/assets/resources/ABA2013Science.pdf.

QGIS Development Team (2021) QGIS Geographic Information System. Open Source Geospatial Foundation Project. http://qgis.osgeo.org

R Core Team (2013). R: A language and environment for statistical computing. R Foundation for Statistical Computing, Vienna, Austria. URL http://www.R-project.org/

Richardson DM, Pyšek P, Rejmánek M, Barbour MG, Panetta FD, West CJ (2000) Naturalization and invasion of alien plants: concepts and definitions. Divers. Distrib. 6: 93-107. https://doi.org/10.1046/j.1472-4642.2000.00083.x.

Soetaert K (2013b) plot3D: Plotting multi-dimensional data. R package version 1.0. https://cran.rproject.org/web/packages/plot3Drgl/vignettes/plot3Drgl.pdf Accessed 29.01.2021

Sortland AB, Thamdrup S, Elven R (2007) En omvendt viking - Senecio pseudoarnica (strandsvineblom) ny for Norge og Europa. Blyttia 65: 86-90. 
Tómasson P (1992) Frásögn af kynnisferð og plöntusöfnun í Austur-Síbiríu. Skógræktarritið 1992: 17-45.

Wasowicz P, Sennikov AN, Westergaard KB, Spellman K, Carlson ML, Gillespie L, Saarela JM, Seefeldt SS, Bennett B, Bay C, Ickert-Bond S, Väre H (2020) Non-native vascular flora of the Arctic: Taxonomic richness, distribution and pathways. Ambio. 49: 693-703. doi: 10.1007/s13280-019-01296-6.

\section{Figures}

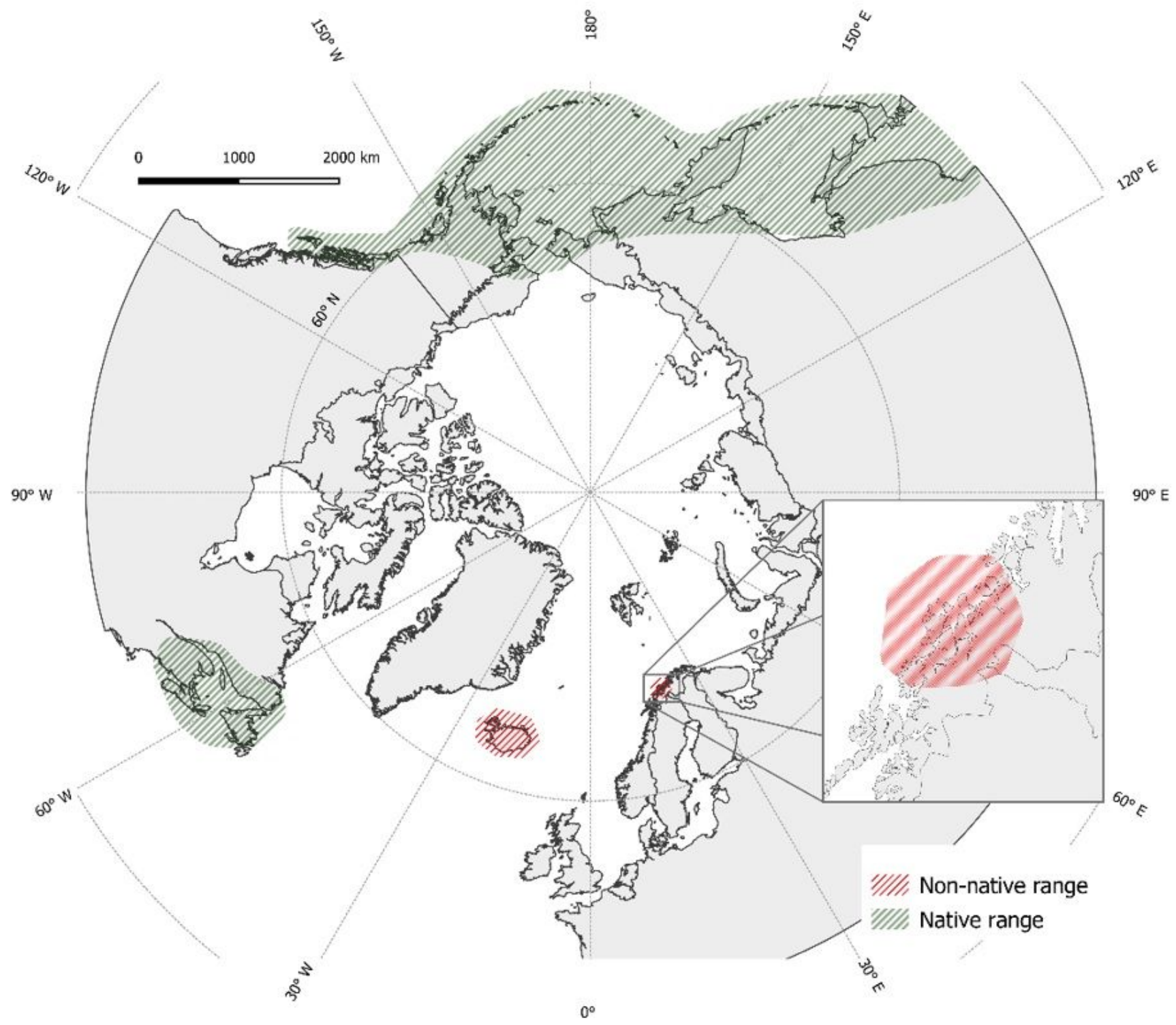

\section{Figure 1}

The native and non-native ranges of Senecio pseudoarnica. 


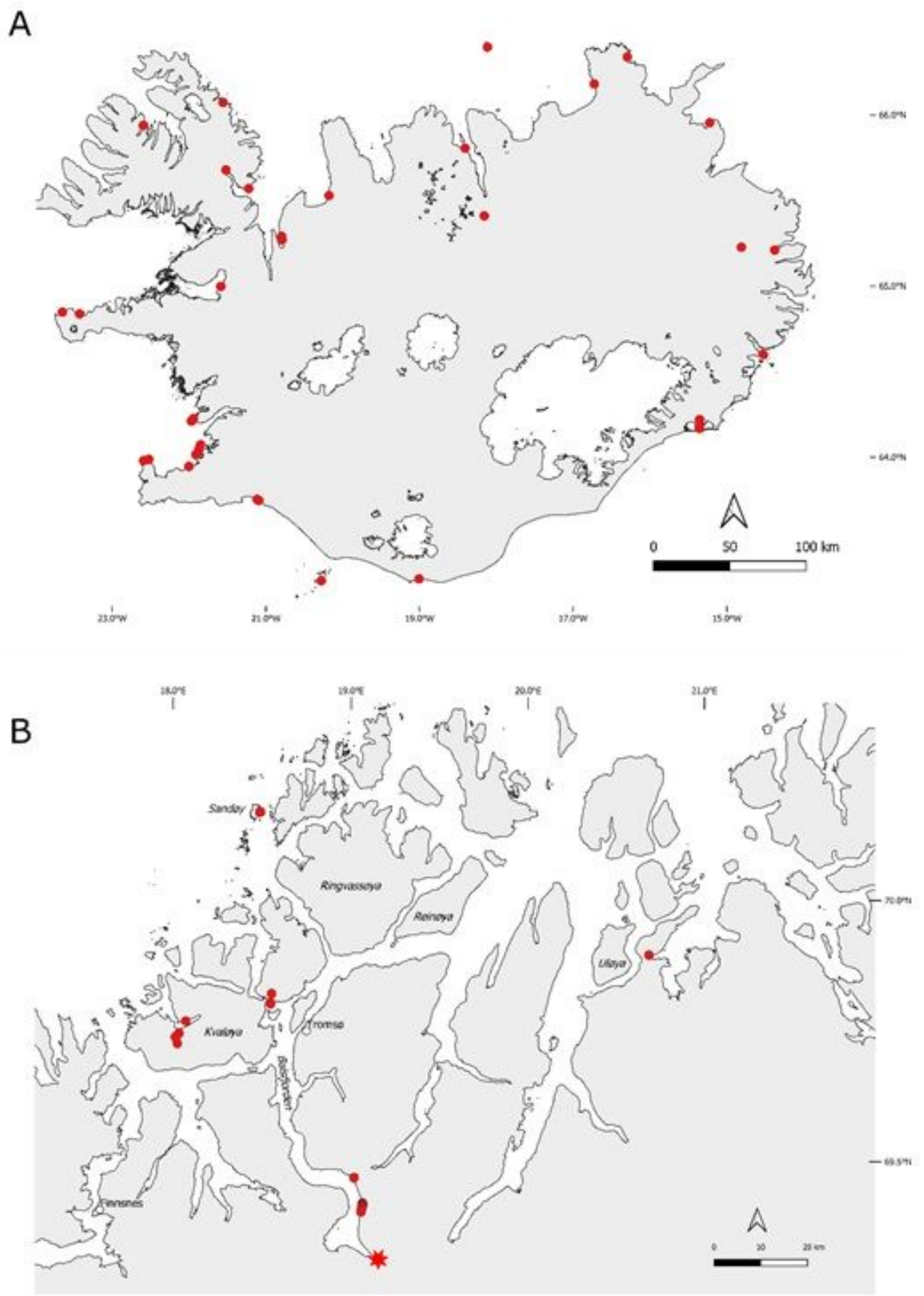

\section{Figure 2}

The distribution of Senecio pseudoarnica in Iceland (A) and Norway (B). The location of its initial introduction in Norway is marked with a star. 


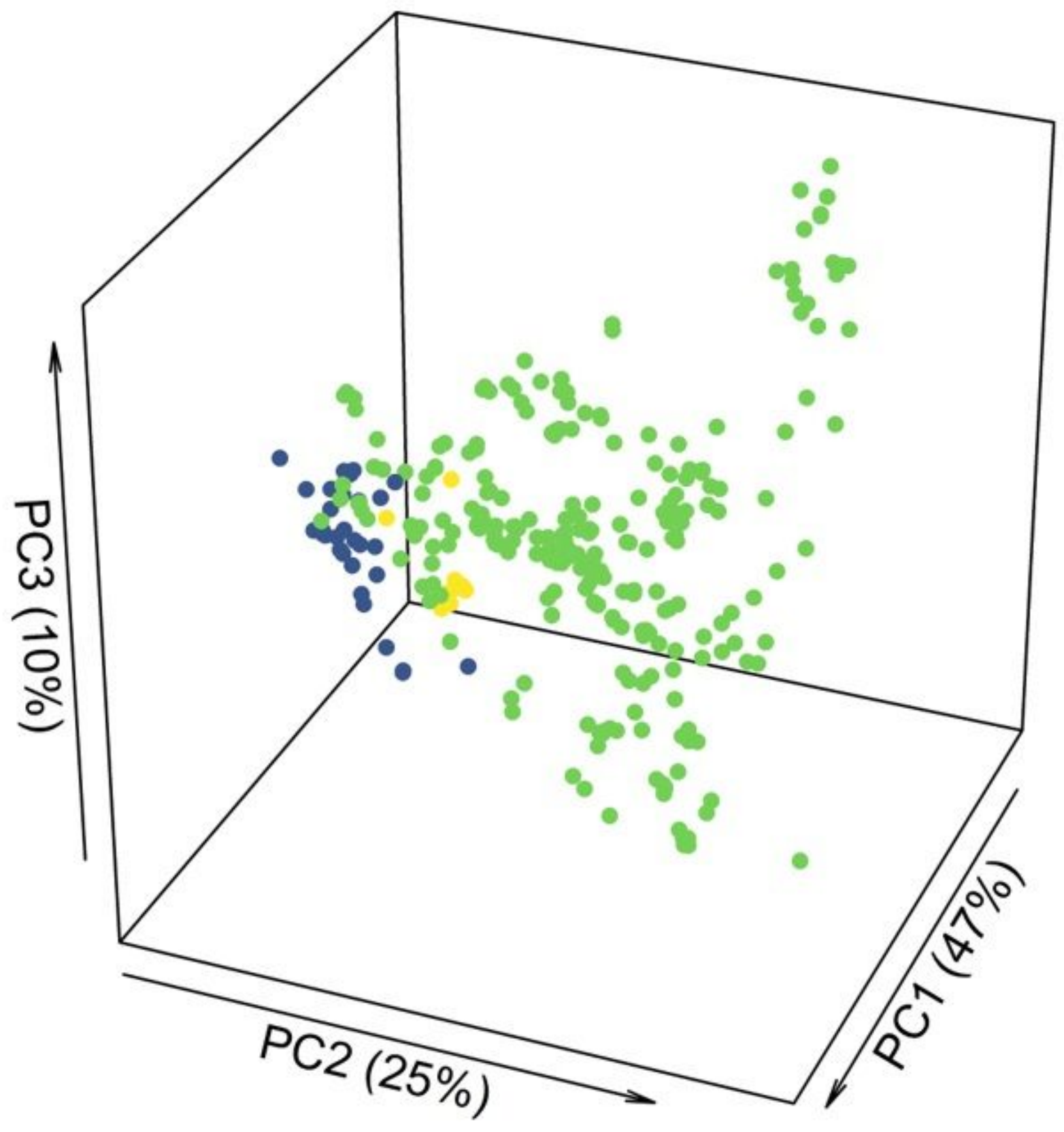

Figure 3

PCA carried out on the matrix of fine-scale $(1 \times 1 \mathrm{~km})$ climatic variables that characterised the climatic conditions in native (green points) and non-native ranges of S. pseudoarnica (Iceland: blue points, Norway: green points). The percentage of variance corresponding to each PC is provided in the axis description. 

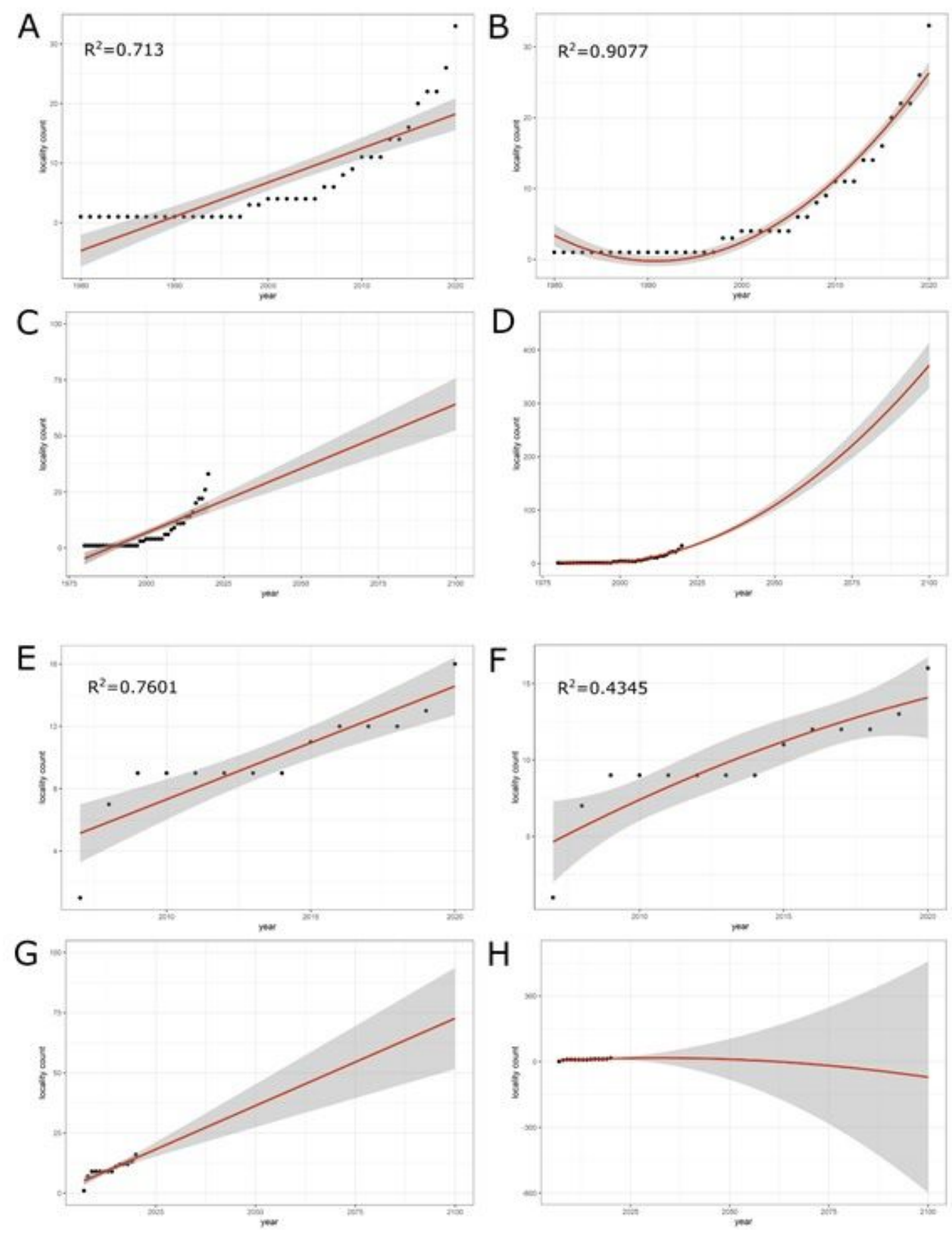

\section{Figure 4}

Fitting observation data with linear and non-linear models and corresponding predictions: a linear model for Iceland: (A) model fitting, (C) predictions; an exponential model for Iceland: (B) model fitting, (D) predictions; a linear model for Norway: $(\mathrm{E})$ model fitting, $(\mathrm{G})$ predictions; and an exponential model for Norway: $(\mathrm{F})$ model fitting, $(\mathrm{H})$ predictions. 